\title{
The Relationship between Share Price Gains, Corporate Performance and Risk
}

\author{
—Empirical Analysis Based on Agriculture, Construction, Finance
}

\section{Yujuan Zhao}

School of Business, Soochow University, Suzhou, Jiangsu Province, China.

Email: Yujuan_zhao@163.com

Received July, 2013

\begin{abstract}
In this paper, we have tested the relationship between the stock returns, corporate performance and investment risks with the sample of listed companies in the agricultural, construction and financial industries in the A-share stock market. Descriptive statistical analysis, correlation test and regression analysis indicate that there is no relationship between stock returns and corporate performance, but there exists a positive correlation between the stock returns and investment risks in the construction and financial industries.
\end{abstract}

Keywords: Share Price Gains, Corporate Performance, Investment Risk

\section{Introduction}

In developed stock markets, share price gains and investment risk, performance of listed companies should have more significant positive correlations. Listed companies in different industries have different market structures, profitability and industry life cycle, so the share price gains, investment risk and the performance of listed companies should also have significant differences. The relationship between share price gains, corporate performance and investment risks have been studied abroad. Colin Clubb, Mounir Naffi have analyzed the relationship between the present and the future book value and returns on equity (ROE). Their log-linear model has a high predictive power for the stock returns of the U.K. listed companies. [1]. Chinese scholars of the research include: On the listed company's stock yields standard deviation and return on equity (ROE), they analyzed the fluctuations in the ratio of the standard deviation[2,3], or studied the time series analysis on listed company's performance and stock price[4,5].

\section{Sample Select}

Our sample includes 51 listed companies in the agricultural, construction and financial industries. The data include the ex-right and ex-dividend stock price at the end of each month, and the financial data in the 36 months from 2009 to 2011. We have applied statistical and econometric methods for empirical studies and analyses, in order to address the following issues:
- Firstly, whether and to what degree there exists correlation between the stock returns and corporate performance and whether there exists industrial differences;

- Secondly, whether there exists correlation between the stock returns and the risks, whether the risks can explain the stock returns, and whether there exists industrial differences.

\subsection{Industry Selection}

We have selected the stocks in the main board for the study. In select research object, we follow the criteria "Three Industries Classification Provisions" (www.stats. gov.cn) published on January 14, 2013. The industries have primary industry A class (agricultural), secondary industry $\mathrm{E}$ class (construction) and tertiary industry I class (finance). We also follow the SFC industry classification to select specific subdivision of industry.

\subsection{Conditions of Sample Select}

The sampling period ranges from 2009 to 2011. The sample companies include those listed companies releasing the annual report during the sample period. Flush software and resset database information are the main object of analysis. We use complex compound interest to adjust the stock price data. Sample stocks have been filtered according to the following criteria:

1) Considering that the A-share market and segmentation of B-share markets, investment and pricing differences, excluding issued B-shares or $\mathrm{H}$-shares votes a 
share listed companies;

2) In view that the shares of newly listed companies do not release enough data and that comparison is prone to error, in order to avoid the effects of new shares, we only select the data of the shares listed before November 31, 2008;

3) Because ST company and some other companies with negative net worth have irregular status, we exclude ST, *ST and PT unit;

4) To avoid the influence of outliers, we exclude companies with defect data and missing data;

5) In order to maintain stability of the sample company, removed during the sample period to change the main business of the company.

Finally, we selected 16 listed companies in the agriculture, 22 listed companies in the construction industry and 13 listed companies in the financial sector.

\section{Index Selection}

This paper has discussed three main indicators: the company performance, stock prices earnings and investment risks.

\subsection{Company Performance}

This paper chose to use the business performance of the most important indicators - Return of Equity(ROE). Return on equity is the company's profit after tax divided by the percentage rate of net assets. The indicators reflect the level of shareholders ' equity income, measuring the shareholders into the company's unit capital receive profits, which companies create value for shareholders, to measure the efficiency of the companies using its own capital. In theory, the higher the modified index values, the better the performance of the company will be.

\subsection{Share Price Gains}

A study on characteristics of months of stock price behavior this article proceeds to month stock return. Stock investors higher yields indicate stock profits gained.

\subsection{Investment Risks}

Risk is measured by deviation of the rate of return on saving. Risk is the uncertainty about profits, so we measure the risks as the absolute value of the difference between the month-end closing price of each stock and the closing price the industries.

\section{Regression Process}

According to descriptive statistical analysis, the average revenue in the construction industry has amounted to $2.75 \%$, the highest in the three sampling industry. Agri- cultural stocks months yield is slightly lower than the construction industry. Finance stock returns are $1.25 \%$, far below the stock months yield in agriculture and construction, basically only one half of the saving rate in the construction industry. From profit risks, profits in the construction industry are $7.26 \%$, lower than agricultural $8.28 \%$. Saving yields the lowest $4.76 \%$, also have the lowest profit value-at-risk in the financial industry, but the value is relative to the yields a higher risk. Judging from the ROE, finance has the value of maximum, $9.48 \%$, agriculture has $4.11 \%$ and construction has $5.11 \%$, respectively, the difference between the two is only $1 \%$, far less than the financial industry ROE. We can conclude that ROE of the financial industry are significantly higher than the other two sectors, indicating generally better performance of the financial sector.

In this article, risk and performance are explanatory variable, for regression analysis of stock returns. Regression models are:

$$
\begin{gathered}
\mathrm{R}=\alpha_{1}+\beta_{1} \sigma+v_{1} \\
\mathrm{R}=\alpha_{2}+\beta_{2} \mathrm{ROE}+\mathrm{v}_{2}
\end{gathered}
$$

$\mathrm{R}, \sigma$, ROE, respectively for the month stock return, risk and profit return on equity;

$\alpha_{1}$ and $\alpha_{2}$ are for intercept, $\beta_{1}$ and $\beta_{2}$ are for regression coefficients; $v_{1}$ and $v_{2}$ are for errors. For the entire company, we take the risk and performance of the company as explanatory variables for regression analysis of stock returns. (1) (2) can have all three respectively by a formula of regression equation:

Agricultural:

$$
\begin{aligned}
& \mathrm{R}=0.030159-0.107312 \sigma \\
& (1.674024) \quad(-0.786377) \\
& \mathrm{R}^{2}=0.017863 \\
& \mathrm{R}=0.054489-0.908144 \mathrm{ROE} \\
& (0.998175) \quad(-0.629839) \\
& \mathrm{R}^{2}=0.011533
\end{aligned}
$$

Construction:

$$
\begin{gathered}
\mathrm{R}=-0.122864+2.071953 \sigma \\
(-2.834386) * * * \quad(3.701295) * * * \\
\mathrm{R}^{2}=0.287206 \\
\mathrm{R}=0.019575+0.154728 \mathrm{ROE} \\
(0.559989) \quad(0.265277) \\
\mathrm{R}^{2}=0.002065
\end{gathered}
$$

Finance:

$$
\begin{gathered}
\mathrm{R}=-0.131175+3.017579 \sigma \\
(-3.592490) * * \quad(4.363768) * * * \\
\mathrm{R}^{2}=0.359004 \\
\mathrm{R}=0.004501+0.084075 \mathrm{ROE}
\end{gathered}
$$




$$
\begin{aligned}
& (0.084193) \quad(0.160409) \\
& \mathrm{R}^{2}=0.000756
\end{aligned}
$$

(**at a confidence level of $95 \%$ significant, $* * *$ at a confidence level of $99 \%$ significant)

The above results indicate the following points:

1) For all industries, with ROE as explanatory variables on stock returns, the regression coefficients are not significant in t-test.

2) Relationship between investment risk and stock returns for agricultural companies' regression is not significant. For the construction industry, at $99 \%$ confidence level, investment risk and stock returns are linearly correlated. Growth of investment risk by $1 \%$ would increase earnings $2.071953 \%$. Financial risk on stock return on investment is significant at $99 \%$ confidence level, which indicates that with increasing investment risk, stock returns will increase.

\section{Conclusions}

The above empirical research on company's performance, investment risk and stock return can come to the following conclusions:

1) In the stock market in China, the relationship between share price gains, investment risk and return on equity in the agricultural and the construction industries are closer, the value of share price gains and investment risk are much lower in comparison, but return on equity of the financial sector is far higher than the two industries. Primary and secondary industries in the Chinese stock market have a strong convergence of the listed company, tertiary industry's share price gains and investment risk but do not match its return on equity. Investors have underestimated as represented by the financial industry's profitability of listed companies of the tertiary industry, and it's better to invest in the companies in the primary and secondary industries.

2) On the construction and the financial sector, share price gains show strong correlation with investment risk. We can consider the proceeds of its share price gains in the construction industry and the financial sector in part as the premium of risk.

3) Listed company's share price gains are out of its performance of listed companies relying on the subject-ROE. This suggests that China's stock markets are strongly speculative. In developed stock markets, investors fully obtain enterprise value on the basis of relevant information to invest in listed companies. In pursuit of maximization of investment wealth, the investors are driven by their preference for the good performance of listed companies. The investors offer high for companies with good performance, and company can only bid low with their poor performance. The process makes capital cost difference, enables the optimization of resources allocation of stock market. In a large number of empirical studies, the mature markets have indicated that most of the listed companies have a good performance and high stock price. China's stock market is an emerging market and still in its transition phase. The system and the market participant in China are not so mature as those in the developed markets. The intermediary organizations are quite weak so the information release is inefficient. The market structures and market rules are still inadequate, so the market has long been characterized by frequent, intense market volatility.

\section{REFERENCES}

[1] C. Clubb and M. Naffi, "The Usefulness of Book-toMarket and ROE Expectations for Explaining UK Stock Returns," Journal of Business Finance and Accounting, Vol. 32, 2007, pp. 1050-1052.

[2] S. Futie, Share Price of Listed Companies Earnings and Return on Equity Research on the Relationship between the Risk of [c]. The Financial Management Annual Meeting Proceedings of the Chambers, 2009.

[3] Q. W. Dai, "Analysis of Factors Affecting the Yield on Shares of Listed Companies in China," Corporate Governance, Vol. 4, 2012, pp. 114-116.

[4] Y. Y. Yan and J. Hu, Stock Price Analysis-associated with the Performance of Listed Companies on China's Stock Market," Systems Engineering, Vol. 24, 2006, pp. 63-69.

[5] C. L. Wang and H. W. Li, Stock Price Impact on the Performance of Listed Companies," Research on Financial and Economic Issues, 2009, No. 5, 56-66. 